\title{
Hetarylazopyrazolone Dyes Based on Benzothiazole and Benzimidazole Ring Systems: Synthesis, Spectroscopic Investigation, and Computational Study
}

\author{
Ebru Aktan and Tahsin Uyar \\ Faculty of Science, Department of Chemistry, Gazi University, Teknikokullar, 06500 Ankara, Turkey \\ Correspondence should be addressed to Ebru Aktan; ebruaktan@gazi.edu.tr
}

Received 3 January 2017; Accepted 22 February 2017; Published 4 April 2017

Academic Editor: James W. Gauld

Copyright (C) 2017 Ebru Aktan and Tahsin Uyar. This is an open access article distributed under the Creative Commons Attribution License, which permits unrestricted use, distribution, and reproduction in any medium, provided the original work is properly cited.

In this study, the synthesized coupling component 1-(2-benzothiazolyl)-3-methylpyrazol-5-one reacted with diazotised heterocyclic amines to afford six novel hetarylazopyrazolone dyes. These azo dyes based on benzothiazole and benzimidazole ring systems were characterized by spectral methods and elemental analyses. The solvatochromic behaviors of these dyes in various solvents were evaluated. The ground state geometries of the dyes were optimized using density functional theory (DFT). Solvent, acid-base, and substituent influences on the wavelength of the maximum absorption were examined in detail. Time-dependent density functional theory (TD-DFT) calculations were performed to obtain the absorption spectra of the dyes in various solvents and the results compared with experimental values. Besides, frontier molecular orbitals (FMO) analysis for the dyes is also described from the computational process.

\section{Introduction}

The ease of availability of raw materials and ease of preparation [1], wide range of uses as dyestuff [2,3], advanced applications such as liquid crystal displays (LCDs) [4], nonlinear optical (NLO) devices [5], dye-sensitized solar cells (DSSCs) [6], optoelectronic systems [7, 8], and wide application areas in biological and medical studies [9] are all desirable characteristics of azo dyes.

Various experimental and theoretical studies on the structure, tautomeric behavior, dyeing properties, and vibrational analysis of azo dyes [10-19] and their metal complexes [20-22] have been done. Due to their chemical significance and spectroscopic properties, hetarylazo dyes were studied extensively by spectroscopic and theoretical methods. Their higher tinctorial strength and brighter dyeing make azo dyes based on heterocyclic amines superior than aniline based azo dyes [23-28]. Some hetarylazopyrazolone dyes have not only potential use as dye stuff, but also other potential nontextile applications such as optical materials [29].

Many studies via theoretical calculations have been performed for determination of the structural, spectroscopic properties, and tautomeric behaviors of azo dyes [30, 31]. Density functional theory (DFT) and time-dependent density functional theory (TD-DFT) have been one of the most widely used methods in computational chemistry [32-37].

We have previously reported the synthesis, characterization, tautomeric behavior, and solvent effects on their absorption spectra of some hetarylazopyrazolone dyes with thiazole moiety together with their theoretical studies [38]. In continuation of this study, we report here the synthesis and characterization of a series of new monoazo dyes based on the benzothiazole and benzimidazole ring systems. Optimization calculations of the dyes in the ground state were done at the DFT B3LYP/6-31G(d,p) level. Absorption spectra based on the DFT-optimized structures were obtained by the timedependent density functional theory (TD-DFT/B3LYP) level with the $6-31 \mathrm{G}(\mathrm{d}, \mathrm{p})$ basis set.

\section{Experimental}

2.1. General. The reagents of analytical grade were purchased from commercial sources and used without any further purification. ${ }^{1} \mathrm{H}$ NMR spectra were measured with a Bruker 


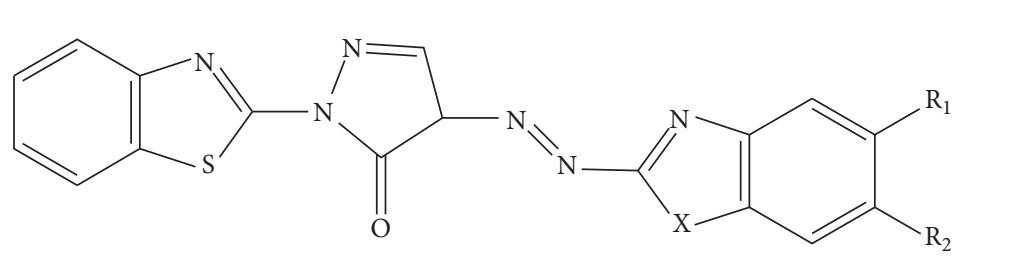

$$
\begin{array}{lll}
\text { Dye } & \multicolumn{2}{c}{\text { Substituents }} \\
\text { 3a } & \mathrm{X}=\mathrm{S} & \mathrm{R}_{1}=\mathrm{R}_{2}=\mathrm{H} \\
\text { 3b } & \mathrm{X}=\mathrm{S} & \mathrm{R}_{1}=\mathrm{H} \quad \mathrm{R}_{2}=\mathrm{Cl} \\
3 \mathrm{c} & \mathrm{X}=\mathrm{S} & \mathrm{R}_{1}=\mathrm{H} \quad \mathrm{R}_{2}=\mathrm{OCH}_{3} \\
\text { 3d } & \mathrm{X}=\mathrm{S} & \mathrm{R}_{1}=\mathrm{R}_{2}=\mathrm{CH}_{3} \\
3 \mathrm{e} & \mathrm{X}=\mathrm{NH} & \mathrm{R}_{1}=\mathrm{R}_{2}=\mathrm{H} \\
3 \mathrm{f} & \mathrm{X}=\mathrm{NH} & \mathrm{R}_{1}=\mathrm{R}_{2}=\mathrm{CH}_{3}
\end{array}
$$

\begin{tabular}{|c|c|c|c|c|c|c|c|c|c|c|c|c|c|}
\hline Dye & Molecular formula & Color ${ }^{a}$ & Cryst. & Yield $^{\mathrm{b}}$ & Melting point & & $\mathrm{C} \%$ & & $\mathrm{H} \%$ & & N\% & & S\% \\
\hline number & $(\mathrm{mol}$ & & solvent & $(\%)$ & $\left({ }^{\circ} \mathrm{C}\right)$ & Calc. & Found & Calc. & Found & Calc. & Found & Calc. & Found \\
\hline $3 a$ & $\mathrm{C}_{18} \mathrm{H}_{12} \mathrm{~N}_{6} \mathrm{OS}_{2}(392.5)$ & Orange & Acetic acid & 87 & $255-257$ & 55.09 & 44.90 & 3.08 & 3.11 & 21.41 & 20.94 & 16.34 & 16.09 \\
\hline $3 b$ & $\mathrm{C}_{18} \mathrm{H}_{11} \mathrm{ClN}_{6} \mathrm{OS}_{2}(426.9)$ & Orange & Acetic acid & 95 & $265-267$ & 50.64 & 50.27 & 2.60 & 2.77 & 19.69 & 19.92 & 15.02 & 14.97 \\
\hline $3 c$ & $\mathrm{C}_{19} \mathrm{H}_{14} \mathrm{~N}_{6} \mathrm{O}_{2} \mathrm{~S}_{2}(422.5)$ & Dark red & Ethanol $^{\mathrm{c}}$ & 56 & $248-250$ & 54.01 & 53.96 & 3.34 & 3.34 & 19.89 & 19.53 & 15.18 & 15.03 \\
\hline $3 \mathrm{~d}$ & $\mathrm{C}_{20} \mathrm{H}_{16} \mathrm{~N}_{6} \mathrm{OS}_{2}$ (420.5) & Orange & Ethanol & 94 & $270-271$ & 57.12 & 56.73 & 3.84 & 3.56 & 19.99 & 19.42 & 15.25 & 14.82 \\
\hline $3 e$ & $\mathrm{C}_{18} \mathrm{H}_{13} \mathrm{~N}_{7} \mathrm{OS}(375.4)$ & Orange & Acetic acid/water & 76 & 294-295 & 57.59 & 57.20 & 3.49 & 3.52 & 26.12 & 25.88 & 8.54 & 8.11 \\
\hline $3 \mathrm{f}$ & $\mathrm{C}_{20} \mathrm{H}_{17} \mathrm{~N}_{7} \mathrm{OS}(403.5)$ & Orange & DMF/water & 81 & 303-304 & 59.54 & 58.93 & 4.25 & 4.33 & 24.3 & 23.77 & 7.95 & 7.64 \\
\hline
\end{tabular}

FIgURE 1: The general route for the synthesis of dyes $3 \mathrm{a}-3 \mathrm{f}$.

TABLE 1: Characterization data and elemental analysis of dyes $3 \mathrm{a}-3 \mathrm{f}$.

${ }^{a}$ Powder.

${ }^{\mathrm{b}}$ Yield of crude product.

${ }^{c}$ Washed with ethanol.

DPX-400 MHz spectrometer at room temperature in DMSO$\mathrm{d}_{6}$ with tetramethylsilane as the internal reference. UV-visible absorption spectra were recorded on Analytik Jena Specord 200 double-beam spectrophotometer, using dimethyl sulfoxide (DMSO), dimethylformamide (DMF), acetonitrile, methanol, acetic acid, and chloroform as solvent. Infrared spectra were taken in $\mathrm{KBr}$ on a Mattson 1000 spectrophotometer. Mass spectra were measured with a Micromass UK Platform II LC-MS spectrometer. Elemental analyses were performed with a LECO-CHNS-9320 instrument. Melting points were obtained with a Gallenkamp capillary melting apparatus and they are uncorrected.

2.2. Synthesis. The methods used for the syntheses of 2hydrazinobenzothiazole (1) and coupling component 1-(2benzothiazolyl)-3-methylpyrazol-5-one (2) were described in the previous part of our study [38].

2.2.1. Synthesis of Hetarylazopyrazolone Dyes (3a-3f). Diazotisation of various amines was affected with nitrosylsulfuric acid. General procedure was described below for 1-(2benzothiazolyl)-3-methyl-4-(2-benzothiazolylazo)pyrazol5 -one and the other dyes were synthesized in a similar way. The characteristic properties and elemental analysis of the dyes are shown in Table 1 . The synthesized dyes (3a-3f) are shown in Figure 1.

2.2.2. Synthesis of 1-(2-Benzothiazolyl)-3-methyl-4-(2-benzothiazolylazo)pyrazol-5-one (1). 2-Aminobenzothiazole (0.002 $\mathrm{mol})$ was dissolved in icy acetic acid-propionic acid mixture $(3 \mathrm{~mL} / 2 \mathrm{~mL})$ and was cooled to $-5^{\circ} \mathrm{C}$ in ice-salt bath. Nitrosylsulfuric acid, prepared with dissolving sodium nitrite $(0.002 \mathrm{~mol}, 0.14 \mathrm{~g})$ in sulfuric acid $(4 \mathrm{~mL})$, was added to the heterocyclic amine dropwise in $30 \mathrm{~min}$ at $-5^{\circ} \mathrm{C}$. The mixture was stirred in cold for additional 2 hours. Urea was added to the mixture in order to decompose the unreacted nitrous acid. 1-(2-Benzothiazolyl)-3-methylpyrazol-5one $(0.002 \mathrm{~mol}, 0.46 \mathrm{~g})$ was dissolved in $\mathrm{KOH}$ solution $(10 \mathrm{~mL}$ $0.2 \mathrm{M}$ ) and cooled. The prepared coupling compound solution was added to the diazonium solution in half an hour. The mixture was stirred for additional 2 hours at $0-5^{\circ} \mathrm{C}$ and $\mathrm{Na}_{2} \mathrm{CO}_{3}$ solution was added till the mixture had a value of pH 5-6. The mixture was stirred for $30 \mathrm{~min}$. Water was added to precipitate the product. The product was filtered, washed with water, and air-dried. Recrystallization was performed in ethanol to obtain the pure orange compound (Yield: $87 \%$ (m.p. 255-257 C)).

2.3. Computational Details. All calculations were carried out with Gaussian09 program [39]. The geometries of the dyes were fully optimized and calculated by B3LYP method and $6-31+G(d)$ basis set without any symmetry constraints. Vibrational frequency analysis confirms that all the optimized geometries correspond to minima on the potential energy surface. Time-dependent density functional theory/integral equation formalism polarisable continuum model (TDDFT/IEFPCM) method has been used to obtain electronic absorption spectra of the dyes [40]. The (default) nonequilibrium procedure was selected for the TD-DFT calculations [41].

\section{Results and Discussion}

3.1. Molecular Structure. Azo dyes can exist in four possible tautomeric forms, namely, the keto-azo forms A and D, ketohydrazo form B, and enol-azo form $\mathrm{C}$ as shown in Figure 2. 


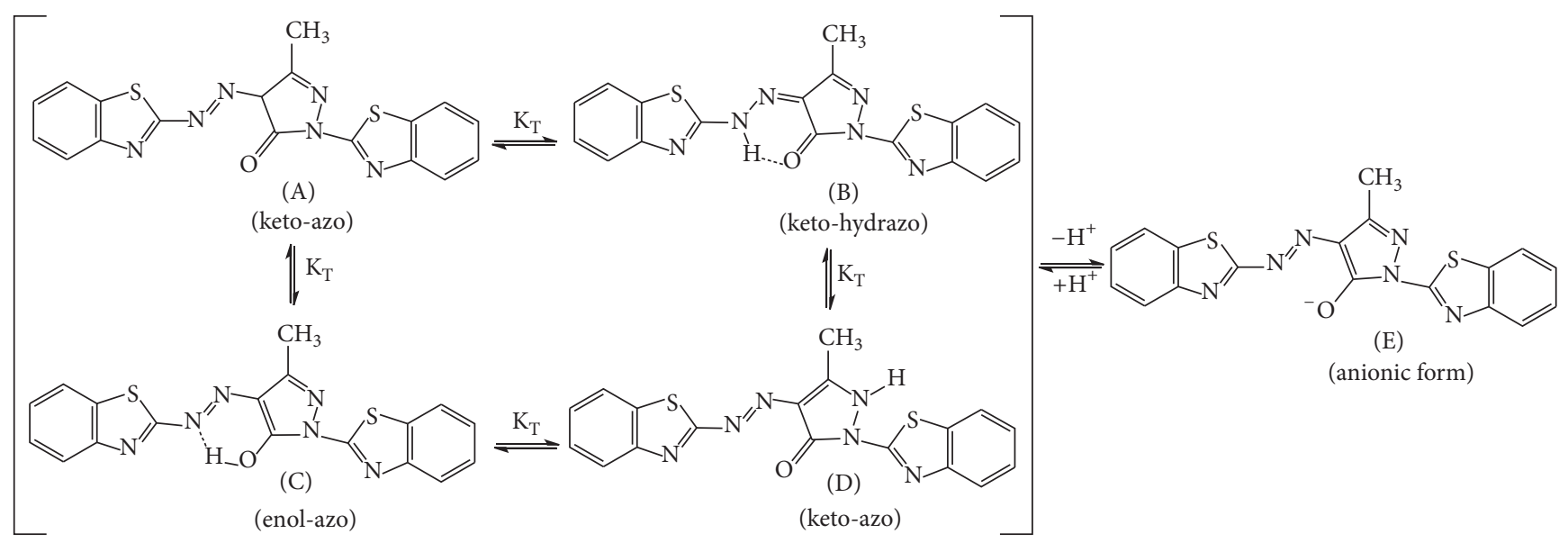

FIgURE 2: Tautomeric equilibrium of dye 3a.

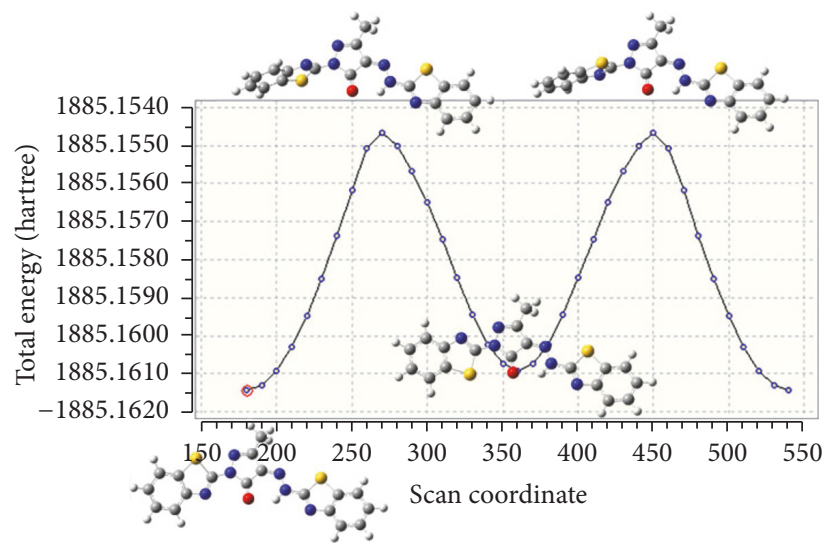

(a)

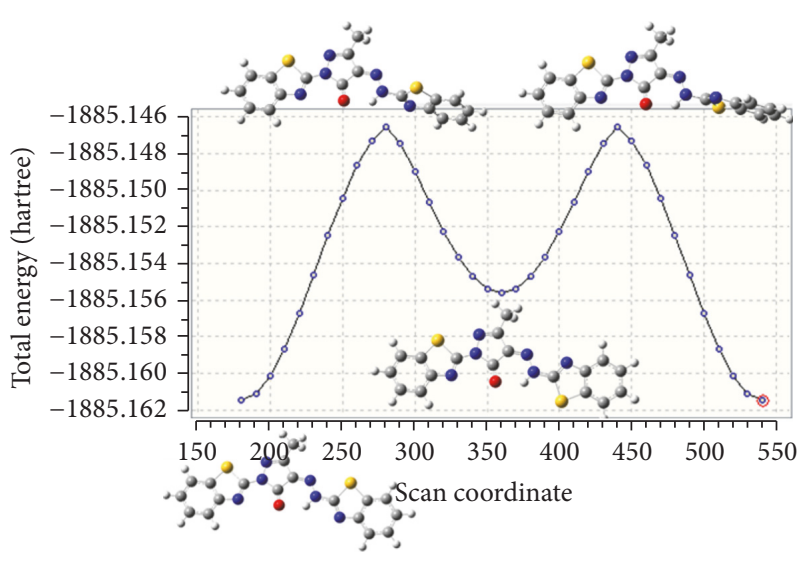

(b)

Figure 3: (a) Scanning graph of the dye 3a on dihedral angle (S24-C7-N22-C13). (b) Scanning graph of the dye 3a on dihedral angle (N26-C16-N19-N27).

The deprotonation of these four tautomers lead to common anion form $\mathrm{E}$.

${ }^{1} \mathrm{H}$ NMR spectrum of dye $3 \mathrm{a}$ exhibits a broad peak at $14.94 \mathrm{ppm}$, which was attributed to $\mathrm{NH}$ of the hydrazo tautomer. This peak was observed at $15.00 \mathrm{ppm}$ for dye $3 \mathrm{~b}$. These results suggest that dyes $3 \mathrm{a}$ and $3 \mathrm{~b}$ are present as ketohydrazo form in DMSO- $\mathrm{d}_{6}$. The absence of hydroxyl $(\mathrm{OH})$, imino $(\mathrm{NH})$, and hydrazo $(\mathrm{NH})$ peaks in the ${ }^{1} \mathrm{H}$ NMR spectra suggests that dyes $3 \mathrm{c}, 3 \mathrm{~d}, 3 \mathrm{e}$, and $3 \mathrm{f}$ exist in keto-azo (A) form or in anionic form (E). The ${ }^{1} \mathrm{H}$ NMR spectra are measured in DMSO- $\mathrm{d}_{6}$ for the dyes except dye $3 \mathrm{c}$, which is recorded in $\mathrm{CDCl}_{3}$. Dye $3 \mathrm{~b}$ showed a singlet peak at $2.30 \mathrm{ppm}$ for methyl group at pyrazolone ring. The ${ }^{1} \mathrm{H}$ NMR spectra for the dyes $3 \mathrm{a}-3 \mathrm{f}$ showed a singlet peak from 2.30 to $2.42 \mathrm{ppm}$ for pyrazolone $\mathrm{CH}_{3}$. Aromatic protons of the dyes 3a-3f appear at 7.00-8.14 ppm. Dye 3c showed a singlet peak at $3.90 \mathrm{ppm}$ for $\mathrm{OCH}_{3}$ proton at benzothiazole ring and a peak at $2.40 \mathrm{ppm}$ for methyl group at pyrazolone ring. Dye $3 \mathrm{~d}$ showed a singlet peak at $2.31 \mathrm{ppm}$ for methyl groups at benzothiazole ring and two doubled peak at $7.79 \mathrm{ppm}$ and $7.99 \mathrm{ppm}$ for aromatic protons at benzothiazole ring. ${ }^{1} \mathrm{H}$ NMR spectra of dyes $3 \mathrm{e}$ and 3f exhibit a broad peak at 13.30 and 13.24 ppm, respectively, which were due to $\mathrm{NH}$ benzimidazole proton.

FT-IR spectra of dyes 3a-3f showed a band at $1638-1684 \mathrm{~cm}^{-1}$ for carbonyl group and a band at $3390-3445 \mathrm{~cm}^{-1}$ for $\mathrm{NH}$ group. These results suggest that these dyes are predominantly in keto-hydrazo (B) form in solid state. The imidazole $\mathrm{NH}$ peaks of the dyes $3 \mathrm{e}$ and $3 \mathrm{f}$ were recorded at $3194 \mathrm{~cm}^{-1}$ and $3147 \mathrm{~cm}^{-1}$. The other $\nu_{\max }$ values of $3021-3070 \mathrm{~cm}^{-1}$ (aromatic $\mathrm{C}-\mathrm{H}$ ) and 2915-2994 cm $\mathrm{cm}^{-1}$ (aliphatic C-H) were also recorded.

The molecular ion $[\mathrm{M}]^{+}$peaks of the dyes are observed at the expected $m / z$ values as the main peak. Dyes give $\left[\mathrm{C}_{11} \mathrm{H}_{8} \mathrm{~N}_{5} \mathrm{OS}\right]^{+}$ion peak at $m / z=258$ except dye $3 \mathrm{c}$ with relative intensities $10-33 \%$. The ion peak $\left[\mathrm{C}_{4} \mathrm{~N}_{2} \mathrm{H}_{3}\right]^{+}$is observed at 79 (10\%) for dye $3 c .{ }^{1} \mathrm{H}$ NMR, FT-IR, and mass spectra results of the dyes are shown in Table 2.

A detailed potential energy scan was performed on dihedral angles (S24-C7-N22-C13) (Figure 3(a)) and (N26-C16-N19-N27) (Figure 3(b)) in the range of $0^{\circ}-360^{\circ}$ at $\mathrm{HF} / 6-31 \mathrm{G}(\mathrm{d})$ level by $10^{\circ}$ intervals to reveal all possible conformations of the dye $3 \mathrm{a}$. 
TABLE 2: Spectral data for dyes 3a-3f.

\begin{tabular}{|c|c|c|c|}
\hline Dye number & ${ }^{1} \mathrm{H}_{-} \mathrm{NMR}^{\mathrm{a}}\left(\mathrm{ppm}, \mathrm{DMSO}-\mathrm{d}_{6}\right)$ & FT-IR $\left(\mathrm{cm}^{-1}, \mathrm{KBr}\right)$ & MS (m/e) \\
\hline \multirow{8}{*}{$3 a$} & $2.30\left(\mathrm{~s}, 3 \mathrm{H}\right.$, pyr $\left.\mathrm{CH}_{3}\right)$ & $3245(\mathrm{~N}-\mathrm{H}), 3070(\mathrm{Ar} \mathrm{C}-\mathrm{H})$ & $393[\mathrm{M}]^{+}(\% 100)$ \\
\hline & 7.35 (m, 2H, bth) & & \\
\hline & $7.48(\mathrm{~m}, 2 \mathrm{H}, \mathrm{bth})$ & & \\
\hline & 7.59 (d, 1H, bth) & & \\
\hline & $7.87(\mathrm{t}, 1 \mathrm{H}, \mathrm{bth})$ & $2915(\mathrm{Al} \mathrm{C}-\mathrm{H}), 1682(\mathrm{C}=\mathrm{O})$ & $258(\% 33)$ \\
\hline & $7.94(\mathrm{~d}, 1 \mathrm{H}, \mathrm{bth})$ & $1595,1523(\mathrm{C}=\mathrm{C}, \mathrm{C}=\mathrm{N})$ & \\
\hline & $8.05(\mathrm{t}, 1 \mathrm{H}, \mathrm{bth})$ & & \\
\hline & $14.94(\mathrm{~b}, \mathrm{NH})$ & & \\
\hline \multirow{3}{*}{$3 b$} & $2.30\left(\mathrm{~s}, 3 \mathrm{H}, \mathrm{pyr} \mathrm{CH}_{3}\right)$ & $3212(\mathrm{~N}-\mathrm{H}), 3062(\mathrm{Ar} \mathrm{C}-\mathrm{H})$ & $427[\mathrm{M}]^{+}(\% 100)$ \\
\hline & 7.33-8.14 (m, 7H, Ar CH) & 2994, $2978(\mathrm{Al} \mathrm{C}-\mathrm{H})$ & \\
\hline & $15.00(\mathrm{~b}, \mathrm{NH})$ & $1684(\mathrm{C}=\mathrm{O}), 1597,1523(\mathrm{C}=\mathrm{C}, \mathrm{C}=\mathrm{N})$ & $258(\% 31)$ \\
\hline \multirow{3}{*}{$3 c^{*}$} & $2.40\left(\mathrm{~s}, 3 \mathrm{H}, \mathrm{pyr} \mathrm{CH}_{3}\right)$ & $3453(\mathrm{~N}-\mathrm{H}), 3070(\mathrm{Ar} \mathrm{C}-\mathrm{H}), 2940(\mathrm{Al} \mathrm{C}-\mathrm{H})$ & $423[\mathrm{M}]^{+}(\% 100)$ \\
\hline & $3.90\left(\mathrm{~s}, 3 \mathrm{H}\right.$, bth $\left.\mathrm{OCH}_{3}\right)$ & & \\
\hline & $7.00-8.10(\mathrm{~m}, 7 \mathrm{H}, \mathrm{Ar} \mathrm{CH})$ & $1670(\mathrm{C}=\mathrm{O}), 1606,1529(\mathrm{C}=\mathrm{C}, \mathrm{C}=\mathrm{N})$ & $79(\% 10)$ \\
\hline \multirow{6}{*}{$3 \mathrm{~d}$} & $2.31\left(\mathrm{~s}, 6 \mathrm{H}\right.$, dimetbth $\left.2 \mathrm{xCH}_{3}\right)$ & $3420(\mathrm{~N}-\mathrm{H}), 3060(\mathrm{Ar} \mathrm{C}-\mathrm{H})$ & $421[\mathrm{M}]^{+}(\% 100)$ \\
\hline & $2.47\left(\mathrm{~s}, 3 \mathrm{H}, \mathrm{pyr} \mathrm{CH}_{3}\right)$ & 2968, $2919(\mathrm{Al} \mathrm{C}-\mathrm{H}), 1638(\mathrm{C}=\mathrm{O})$ & \\
\hline & $7.42(\mathrm{t}, 1 \mathrm{H}, \mathrm{bth})$ & $1557,1519(\mathrm{C}=\mathrm{C}, \mathrm{C}=\mathrm{N})$ & $258(\% 16)$ \\
\hline & 7.52 (s, 1H, dimetbth) & & \\
\hline & 7.61 (s, 1H, dimetbth) & & \\
\hline & $7.79(\mathrm{~d}, 1 \mathrm{H}, \mathrm{bth})$ & & \\
\hline \multirow{3}{*}{$3 \mathrm{e}$} & $2.41\left(\mathrm{~s}, 3 \mathrm{H}\right.$, pyr $\left.\mathrm{CH}_{3}\right)$ & $3416(\mathrm{~N}-\mathrm{H}), 3194$ (benzimidazole N-H), & $376[\mathrm{M}]^{+}(\% 100)$ \\
\hline & 7.21-7.97 (m, 6H, Ar CH) & 3057 (Ar C-H), 2935 (Al C-H) & \\
\hline & $13.30(\mathrm{~b}$, bimi NH$)$ & $1658(\mathrm{C}=\mathrm{O}), 1621,1570(\mathrm{C}=\mathrm{C}, \mathrm{C}=\mathrm{N})$ & $258(\% 43)$ \\
\hline \multirow{4}{*}{$3 f$} & $2.33\left(\mathrm{~s}, 6 \mathrm{H}\right.$, dimetbimi- $\left.2 \mathrm{xCH}_{3}\right)$ & $3390(\mathrm{~N}-\mathrm{H}), 3147$ (benzimidazole $\mathrm{N}-\mathrm{H})$, & $404[\mathrm{M}]^{+}(\% 100)$ \\
\hline & $2.42\left(\mathrm{~s}, 3 \mathrm{H}, \mathrm{pyr} \mathrm{CH}_{3}\right)$ & $3021(\mathrm{Ar} \mathrm{C}-\mathrm{H})$ & \\
\hline & 7.34-8.14 (m, 6H, Ar CH) & $2967(\mathrm{Al} \mathrm{C}-\mathrm{H}), 1669(\mathrm{C}=\mathrm{O})$ & $258(\% 10)$ \\
\hline & 13.23 (b, dimethylbenzimidazole NH) & $1616,1529(\mathrm{C}=\mathrm{C}, \mathrm{C}=\mathrm{N})$ & \\
\hline
\end{tabular}

${ }^{a}$ s, singlet; d, doublet; t, triplet; $m$, multiplet; b, broad. pyr: pyrazolone, bth: benzothiazole, and dimetbth: dimethylbenzothiazole. bimi: benzimidazole; dimetbimi: dimethylbenzimidazole.

${ }^{* 1} \mathrm{H}-\mathrm{NMR}$ in $\mathrm{CHCl}_{3}$.

Then, final geometry optimizations were performed within the framework of DFT/B3LYP at the level of 6$31+G(d)$ without any geometrical restriction. The most stable conformation of the keto-hydrazo tautomer is shown in Figure 4 with atomic numbering.

3.2. Effect of Solvent. The UV-Vis absorption spectra of the dyes $3 \mathrm{a}-3 \mathrm{f}$ were recorded over the range of $\lambda$ between 300 and $700 \mathrm{~nm}$ and the results are given in Table 3 .

$\lambda_{\max }$ values of dye $3 \mathrm{a}$, dye $3 \mathrm{~b}$, and dye $3 \mathrm{c}$ exhibit bathochromic shift in methanol, DMF, and DMSO. These dyes show only one maximum and also only one tautomeric form in all solvents. The isosbestic points are around $442 \mathrm{~nm}$, $435 \mathrm{~nm}$, and $465 \mathrm{~nm}$, respectively. Absorption spectra of dye $3 \mathrm{~b}$ in various solvents are given in Figure 5. It was determined that the absorption maxima of the dye $3 \mathrm{~d}$ in methanol, DMF, and DMSO show no significant change, despite blue shift in chloroform and acetic acid. The difference between the experimental absorption maxima of dyes in the most apolar solvent chloroform and in the most polar solvent
DMSO we used lies between 5 and $50 \mathrm{~nm}$ while the calculated absorption maxima of each dye do not change significantly with solvent polarity (max. $4 \mathrm{~nm}$ ). The difference between the experimental and calculated absorption maxima lies between 0 and $36 \mathrm{~nm}$. The absorption maxima of dye $3 \mathrm{e}$ and dye $3 \mathrm{f}$ vary less with the solvent. All of the absorption bands of the dye $3 \mathrm{e}$ and dye $3 \mathrm{f}$ show shoulders in a short wavelength, and their symmetries are distorted. The shoulders can be attributed either to the interference of a tautomer over the dominant one or to the transitions $\pi-\pi^{*}, \mathrm{n}-\pi^{*}$, or charge transfer transitions.

Maximum absorption values and oscillator strengths of the dyes were calculated by using the TD-DFT/IEFPCM method with 6-31G(d,p) basis set in different solvents and the results are shown in Table 4.

3.3. Effect of Acid and Base. Acid-base effects on the absorption spectra of the dyes were investigated. Changes in the maximum absorption wavelength of the dyes with different solvents obtained by addition of the acid-base solution are also provided in Table 5 . 


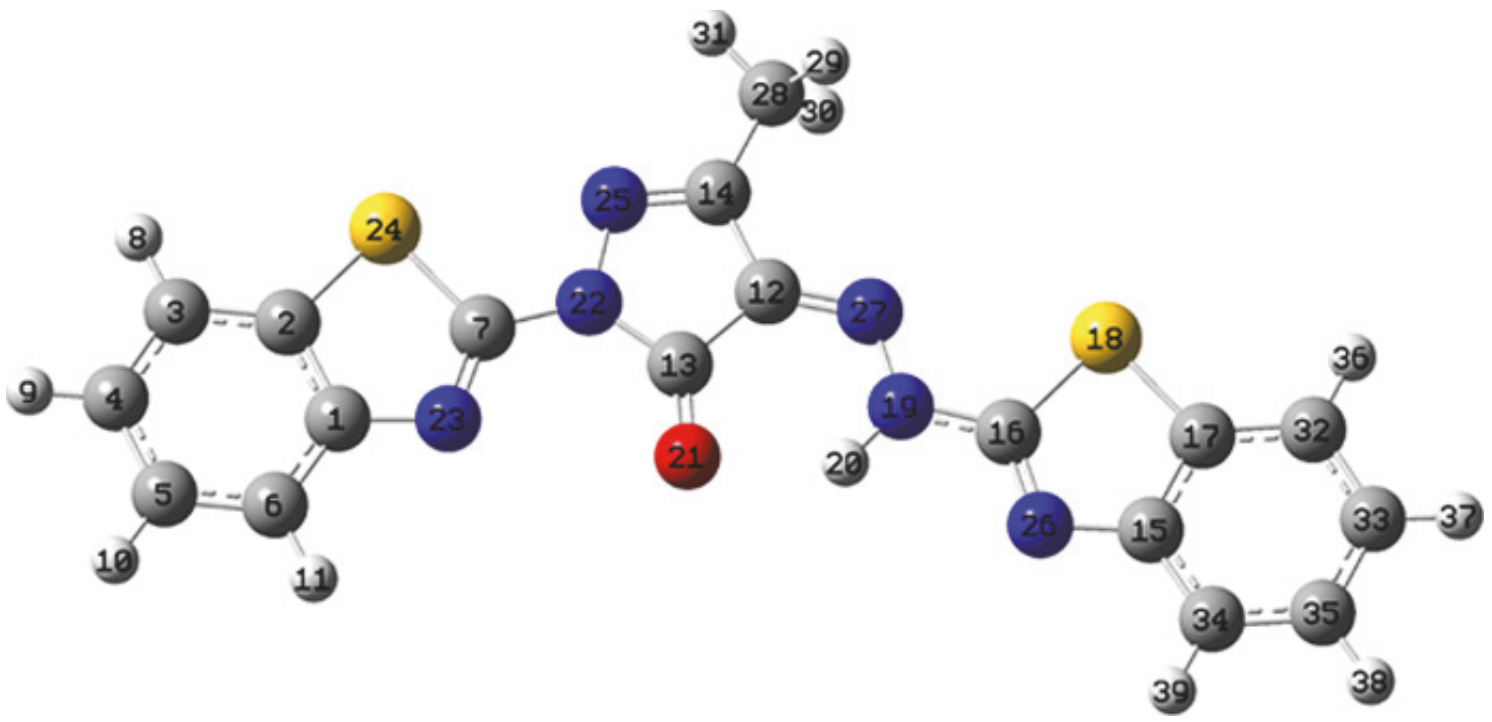

FIGURE 4: Computed optimized ground state geometry with atomic numbering of dye 3a using DFT.

TABLE 3: Influence of solvent on $\lambda_{\max }(\mathrm{nm})$ of dyes 3a-3f.

\begin{tabular}{|c|c|c|c|c|c|c|c|c|}
\hline Dye number & & Chloroform & Acetic acid & Methanol & Acetonitrile & DMF $(\log \varepsilon)$ & DMSO & $\Delta \lambda_{\max }{ }^{a}$ \\
\hline \multirow{2}{*}{$3 a$} & Exp. & 419 & 408 & 457 & 411 & $467(4.443)$ & 469 & \multirow{2}{*}{50} \\
\hline & Calc. $^{\mathrm{b}}$ & $433(0.9087)$ & $432(0.8890)$ & $434(0.8672)$ & $432(0.8779)$ & $434(0.9028)$ & $433(0.8990)$ & \\
\hline \multirow{2}{*}{$3 b$} & Exp. & 421 & 409 & 459 & 412 & $469(4.460)$ & 469 & \multirow{2}{*}{48} \\
\hline & Calc. & $439(0.9685)$ & $438(0.9548)$ & $438(0.9502)$ & $437(0.9543)$ & $439(0.9742)$ & $439(0.9715)$ & \\
\hline \multirow{2}{*}{$3 c$} & Exp. & 450 & 434 & 467 & 469 & 469 (4.569) & 469 & \multirow{2}{*}{19} \\
\hline & Calc. & $488(0.8218)$ & $487(0.8212)$ & $486(0.8268)$ & $488(0.8240)$ & $490(0.8392)$ & $490(0.8372)$ & \\
\hline \multirow{2}{*}{$3 \mathrm{~d}$} & Exp. & 450 & 425 & 465 & 462 & $469(4.774)$ & 473 & \multirow{2}{*}{23} \\
\hline & Calc. & $462(0.8391)$ & $461(0.8168)$ & $462(0.7946)$ & $462(0.7981)$ & $464(0.8060)$ & $463(0.8026)$ & \\
\hline \multirow{2}{*}{$3 e$} & Exp. & 452 & $397^{\mathrm{s}}, 449$ & $401^{s}, 442$ & $400^{s}, 449$ & $453(4.576)$ & 461 & \multirow{2}{*}{9} \\
\hline & Calc. & $447(0.9126)$ & $449(0.9206)$ & $446(0.9126)$ & $447(0.9158)$ & $449(0.9307)$ & $449(0.9286)$ & \\
\hline \multirow{2}{*}{$3 \mathrm{f}$} & Exp. & 464 & 461 & 460 & 462 & 459 (4.649) & 469 & \multirow{2}{*}{5} \\
\hline & Calc. & $480(0.8510)$ & $482(0.8528)$ & $480(0.8510)$ & $481(0.8544)$ & $483(0.8710)$ & $483(0.8688)$ & \\
\hline
\end{tabular}

${ }^{\mathrm{a}} \lambda_{\max }(\mathrm{DMSO})-\lambda_{\max }\left(\mathrm{CHCl}_{3}\right)$; ${ }^{\mathrm{b}}$ oscillator strengths are given in the parentheses; ${ }^{\mathrm{s}}$ shoulder.

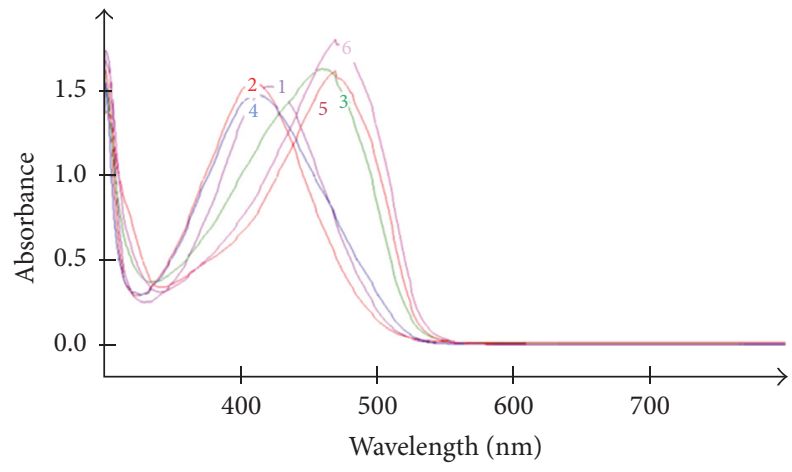
(1) Chloroform
(4) Acetonitrile
(2) Acetic acid
(5) DMF
(3) Methanol
(6) DMSO

FIGURE 5: Absorption spectra of dye $3 \mathrm{~b}$ in various solvents.
When acid was added to the methanol solutions of the dyes $3 \mathrm{c}, 3 \mathrm{~d}$, and $3 \mathrm{e}$, the absorption maxima shift to the bathochromic area while the absorption maxima of the dyes $3 \mathrm{a}$ and $3 \mathrm{~b}$ shift to the hypsochromic area. By the addition of $\mathrm{KOH}$ to methanol solutions of the dyes hypsochromic shifts were observed for dye $3 \mathrm{f}$ and the other dyes did not represent a significant change by their absorption maxima.

The absorption spectra of the dyes in chloroform are sensitive to the addition of piperidine while piperidine addition to DMF and DMSO solutions led to no notable change in the absorption spectra. When piperidine was added to chloroform solution the absorption peaks obtained are similar to the ones measured in DMF and DMSO solutions. There is no significant change in the absorption spectra of the dyes by the addition of trifluoroacetic acid to the chloroform solutions. Absorption spectra of dye $3 \mathrm{a}$ in acid and base are given in Figure 6. 
TABLE 4: Calculated structural parameters (bond lengths in $\AA$, angles in degree) of the dyes $3 \mathrm{a}-3 \mathrm{f}$.

\begin{tabular}{|c|c|c|c|c|c|c|}
\hline \multirow{2}{*}{ Parameter } & \multicolumn{6}{|c|}{ Dyes } \\
\hline & $3 a$ & $3 b$ & $3 c$ & $3 \mathrm{~d}$ & $3 e$ & $3 \mathrm{f}$ \\
\hline \multicolumn{7}{|l|}{ Bond lengths } \\
\hline $\mathrm{C} 2-\mathrm{S} 24$ & 1.759 & 1.759 & 1.759 & 1.759 & 1.759 & 1.759 \\
\hline S24-C7 & 1.781 & 1.780 & 1.781 & 1.781 & 1.781 & 1.781 \\
\hline C7-N23 & 1.290 & 1.290 & 1.290 & 1.290 & 1.290 & 1.290 \\
\hline $\mathrm{C} 1-\mathrm{N} 23$ & 1.388 & 1.388 & 1.388 & 1.388 & 1.388 & 1.388 \\
\hline C7-N22 & 1.389 & 1.390 & 1.389 & 1.389 & 1.389 & 1.389 \\
\hline N22-N25 & 1.405 & 1.405 & 1.405 & 1.405 & 1.404 & 1.404 \\
\hline $\mathrm{C} 13-\mathrm{O} 21$ & 1.229 & 1.229 & 1.229 & 1.229 & 1.229 & 1.229 \\
\hline $\mathrm{C} 12-\mathrm{N} 27$ & 1.307 & 1.306 & 1.309 & 1.308 & 1.310 & 1.311 \\
\hline N27-N19 & 1.319 & 1.321 & 1.317 & 1.318 & 1.319 & 1.317 \\
\hline N19-C16 & 1.381 & 1.380 & 1.382 & 1.382 & 1.382 & 1.382 \\
\hline C16-S18(N18) & 1.771 & 1.773 & 1.774 & 1.772 & 1.371 & 1.371 \\
\hline C16-N26 & 1.294 & 1.294 & 1.294 & 1.295 & 1.310 & 1.310 \\
\hline S18(N18)-C17 & 1.763 & 1.761 & 1.762 & 1.763 & 1.391 & 1.391 \\
\hline $\mathrm{N} 26-\mathrm{C} 15$ & 1.386 & 1.385 & 1.385 & 1.386 & 1.389 & 1.389 \\
\hline \multicolumn{7}{|l|}{ Bond angles } \\
\hline S24-C7-N23 & 117.5 & 117.5 & 117.5 & 117.5 & 117.5 & 117.5 \\
\hline N23-C7-N22 & 124.4 & 124.3 & 118.1 & 124.4 & 118.1 & 118.1 \\
\hline C7-N22-N25 & 118.0 & 118.0 & 118.0 & 118.0 & 118.0 & 118.0 \\
\hline N25-C14-C12 & 110.4 & 110.3 & 110.4 & 110.4 & 110.4 & 110.5 \\
\hline $\mathrm{N} 22-\mathrm{C} 13-\mathrm{O} 21$ & 129.8 & 129.8 & 129.7 & 129.7 & 129.7 & 127.6 \\
\hline C13-C12-N27 & 127.2 & 127.1 & 127.1 & 127.2 & 127.0 & 127.0 \\
\hline N27-N19-C16 & 120.3 & 120.2 & 120.4 & 120.4 & 119.9 & 120.0 \\
\hline N19-C16-S18 & 120.8 & 120.6 & 120.8 & 120.8 & 121.9 & 121.9 \\
\hline C16-N26-C15 & 110.1 & 110.1 & 110.1 & 110.0 & 104.1 & 104.0 \\
\hline \multicolumn{7}{|l|}{ Torsion angles } \\
\hline S24-C7-N22-N25 & 0.0 & 0.0 & 0.0 & 0.0 & 0.0 & 0.0 \\
\hline N22-N25-C14-C28 & 180.0 & 180.0 & 180.0 & 180.0 & 180.0 & 180.0 \\
\hline O21-C13-C12-N27 & 0.0 & 0.0 & 0.0 & 0.0 & 0.0 & 0.0 \\
\hline N27-N19-C16-N26 & 180.0 & 180.0 & 180.0 & 180.0 & 180.0 & 180.0 \\
\hline N19-C16-N26-C15 & 180.0 & 180.0 & 180.0 & 180.0 & 180.0 & 180.0 \\
\hline
\end{tabular}

TABLE 5: Absorption maxima of dyes in acidic and basic solutions.

\begin{tabular}{lcccccccccc}
\hline $\begin{array}{l}\text { Dye } \\
\text { number }\end{array}$ & Methanol & $\begin{array}{c}\text { Methanol + } \\
\mathrm{HCl}\end{array}$ & $\begin{array}{c}\text { Methanol+ } \\
\mathrm{KOH}\end{array}$ & $\mathrm{CHCl}_{3}$ & $\begin{array}{c}\mathrm{CHCl}_{3}+ \\
\mathrm{TFAA}\end{array}$ & $\begin{array}{c}\mathrm{CHCl}_{3}+ \\
\text { piperidin }\end{array}$ & DMF & $\begin{array}{c}\mathrm{DMF}+ \\
\text { piperidin }\end{array}$ & $\begin{array}{c}\mathrm{DMSO} \\
\text { piperidin }\end{array}$ \\
\hline 3a & 457 & 440 & 459 & 418 & 418 & 469 & 469 & 469 & 469 & 469 \\
3b & 462 & 440 & 463 & 422 & 420 & 469 & 469 & 469 & 469 \\
3c & 467 & 479 & 466 & 450 & 452 & 469 & 469 & 469 & 472 & 469 \\
3d & 465 & 477 & 465 & 450 & 449 & 469 & 469 & 469 & 469 & 469 \\
3e & $400^{\mathrm{s}}, 442$ & 453 & $400^{\mathrm{s}}, 442$ & 452 & 451 & 457 & 457 & 457 & 461 & 461 \\
3f & 460 & 462 & 449 & 464 & 464 & 464 & 462 & 462 & 469 & 469 \\
\hline
\end{tabular}

TFAA: trifluoroacetic acid.

${ }^{s}$ shoulder.

Absorption spectra of the dyes $3 \mathrm{a}-3 \mathrm{f}$ were taken in pure chloroform and chloroform/DMF mixtures of $80 / 20$, $60 / 40,40 / 60,20 / 80(\mathrm{v} / \mathrm{v})$, and pure DMF to understand whether the bathochromic shift results from tautomerization or ionization in basic chloroform solution (Table 6). Even a slight increase in the percentage of DMF in chloroform solution shifted the absorption maxima of the dyes $3 a-3 d$ to a sudden longer wavelength. These results suggest that 
TABLE 6: The $\lambda_{\max }$ values of dyes in different percentages of chloroform/DMF mixture.

\begin{tabular}{|c|c|c|c|c|c|c|}
\hline Dye number & Chloroform & $20 \% \mathrm{DMF}$ & $40 \% \mathrm{DMF}$ & $60 \% \mathrm{DMF}$ & $80 \% \mathrm{DMF}$ & DMF \\
\hline $3 a$ & 419 & 445 & 466 & 466 & 467 & 467 \\
\hline $3 b$ & 422 & 460 & 461 & 469 & 469 & 469 \\
\hline $3 c$ & 451 & 469 & 469 & 469 & 469 & 469 \\
\hline $3 d$ & 443 & 453 & 469 & 469 & 469 & 469 \\
\hline $3 e$ & 453 & 459 & 459 & 457 & 453 & 452 \\
\hline $3 \mathrm{f}$ & 465 & 468 & 469 & 467 & 467 & 457 \\
\hline
\end{tabular}

TABLE 7: The maximum absorption wavelengths ( $\mathrm{nm}$ ) of dyes at different temperature and concentration in chloroform and DMF.

\begin{tabular}{|c|c|c|c|c|c|c|}
\hline \multirow[b]{2}{*}{ Dye number } & \multicolumn{3}{|c|}{ Chloroform } & \multicolumn{3}{|c|}{$\mathrm{DMF}$} \\
\hline & $\begin{array}{c}\text { Concentrated } \\
\left(25^{\circ} \mathrm{C}\right) \\
\end{array}$ & $\begin{array}{c}\text { Concentrated } \\
\left(40^{\circ} \mathrm{C}\right)\end{array}$ & $\begin{array}{l}\text { Diluted } \\
\left(25^{\circ} \mathrm{C}\right) \\
\end{array}$ & $\begin{array}{c}\text { Concentrated } \\
\left(25^{\circ} \mathrm{C}\right)\end{array}$ & $\begin{array}{c}\text { Concentrated } \\
\left(40^{\circ} \mathrm{C}\right)\end{array}$ & $\begin{array}{l}\text { Diluted } \\
\left(25^{\circ} \mathrm{C}\right) \\
\end{array}$ \\
\hline $3 a$ & 419 & 417 & 418 & 470 & 468 & 467 \\
\hline $3 b$ & 421 & 420 & 422 & 469 & 469 & 469 \\
\hline $3 c$ & 450 & 450 & 450 & 469 & 469 & 469 \\
\hline $3 d$ & 450 & 449 & 450 & 469 & 469 & 469 \\
\hline $3 e$ & 452 & 452 & 452 & 452 & 452 & 453 \\
\hline $3 \mathrm{f}$ & 464 & 464 & 463 & 457 & 457 & 459 \\
\hline
\end{tabular}

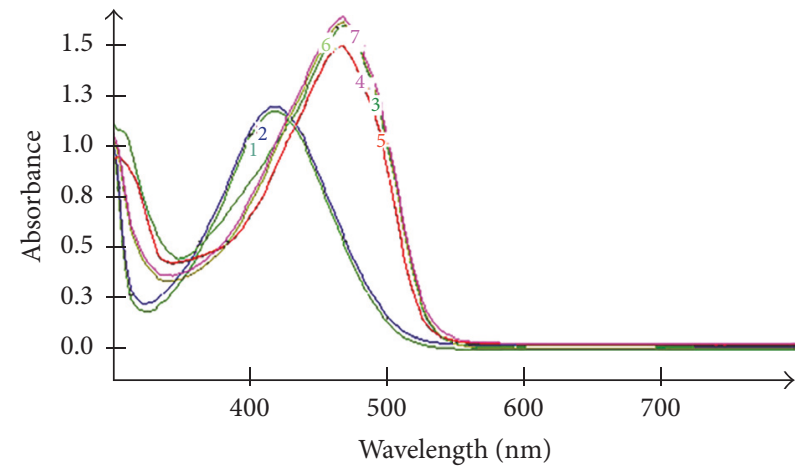
(1) Chloroform
(5) $\mathrm{DMF}+$ piperidine
(2) Chloroform + trifluoroacetic acid
(6) DMSO
(3) Chloroform + piperidine
(7) DMSO + piperidine
(4) DMF

Figure 6: Absorption spectra of dye 3a in acid and base.

these dyes absorbed at long wavelength exist in anionic form. But such a shift was not observed for the dyes $3 \mathrm{e}$ and 3f.

3.4. Effect of Concentration and Temperature. The effect of molarity and temperature on the absorption spectra of the dyes $3 \mathrm{a}-3 \mathrm{f}$ was studied and the results are listed in Table 7. Therefore, chloroform and DMF solutions were diluted 50\% and the absorption spectra were recorded at $25^{\circ} \mathrm{C}$ versus $40^{\circ} \mathrm{C}$. The difference between the $\lambda_{\max }$ values of the neutral molecule and the anion is in the range $1-48 \mathrm{~nm}$. The dyes can easily ionize even in neutral polar solvents and the equilibrium resulting from the solvent change is an ionic equilibrium rather than a tautomeric equilibrium. As seen in Table 7, the absorption spectra are not affected by the concentration and temperature. The reason for this can be ionic equilibria.

3.5. Effect of Substituent. As seen in Table 4, the substituent effect is mostly observed in the most apolar solvent chloroform among all the solvents. The substituent affected $\lambda_{\max }$ values less in DMF and DMSO when compared to other solvents. The substituent effect on $\lambda_{\max }$ values in chloroform is evaluated and the results can be summarized as follows:

(i) The introduction of chlorine group into the sixth position of the benzothiazole ring did not have a notable effect on the absorption maxima. On the other hand, substitution of the methoxy group on the sixth position in dye $3 \mathrm{c}$ and methyl groups on the fifth and sixth position in dye $3 \mathrm{~d}$ had the equal effect on $\lambda_{\max }$ values resulting in $31 \mathrm{~nm}$ bathochromic shift.

(ii) The substituted methyl groups on the fifth and sixth positions on the benzimidazole ring in dye $3 \mathrm{f}$ caused $12 \mathrm{~nm}$ increase in bathochromic shift when it is compared with dye $3 \mathrm{e}$.

(iii) As the electron donating ability of the substituents on the benzothiazole and benzimidazole in diazo compound increases, more electron donation occurs and in parallel to this bathochromic shift also increases.

3.6. Frontier Molecular Orbitals (FMOs). DFT computational results given in Table 7 reveal that the energy gaps $(\Delta E=$ $\left.E_{\mathrm{LUMO}}-E_{\mathrm{HOMO}}\right)$ for benzothiazole moiety bearing azo dyes $3 \mathrm{a}-3 \mathrm{~d}$ are $3.08,3.04,2.85$, and $3.01 \mathrm{eV}$, respectively, while those for the benzimidazole moiety bearing azo dyes $3 \mathrm{e}$ and $3 \mathrm{f}$ are 3.04 and $2.87 \mathrm{eV}$, respectively. The frontier orbitals LUMO+1, LUMO, HOMO, and HOMO+1 are represented in Figure 7. HOMOs and LUMOs of the dyes 3a-3d 

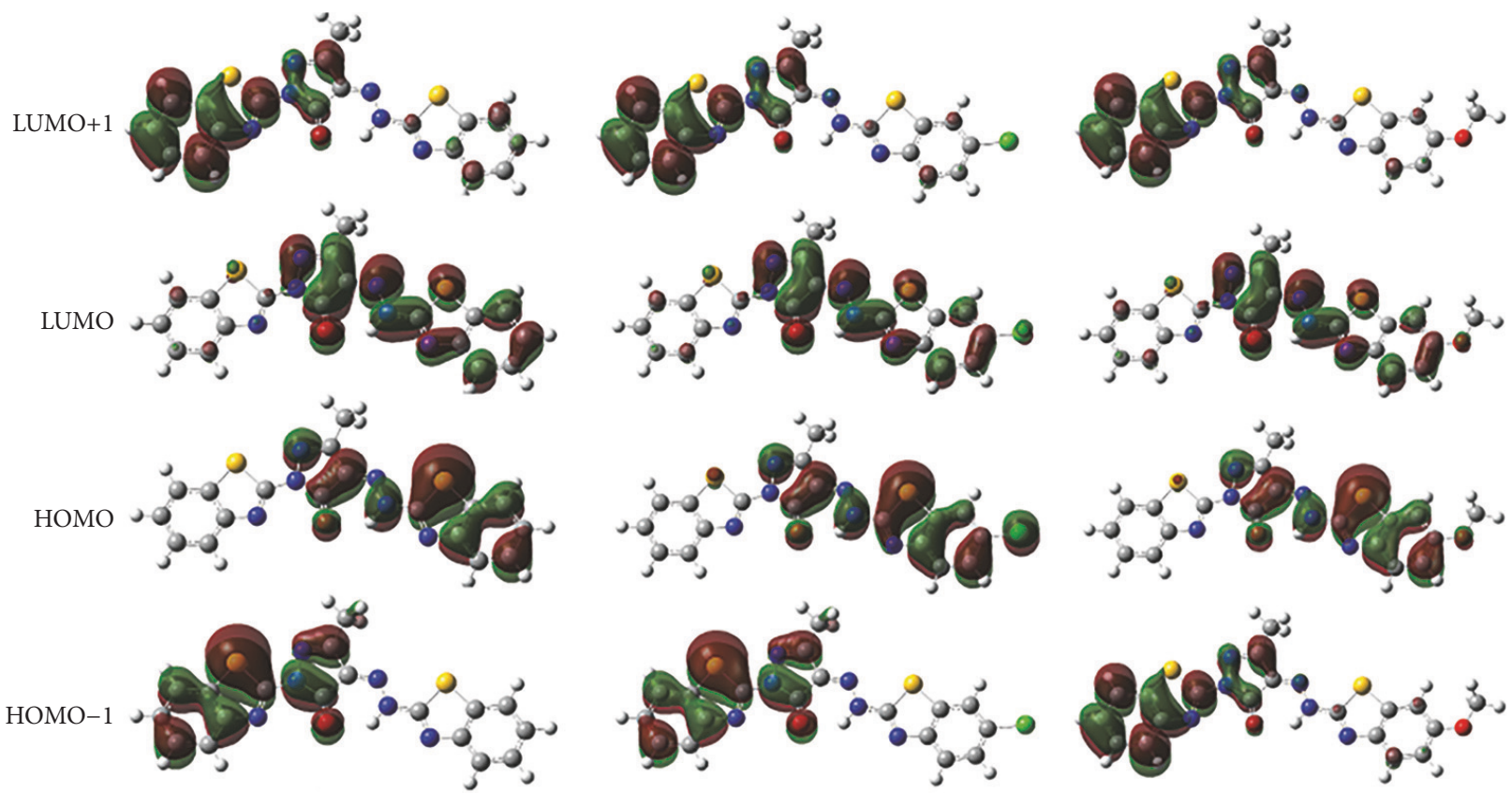

$3 \mathrm{~b}$

$3 c$
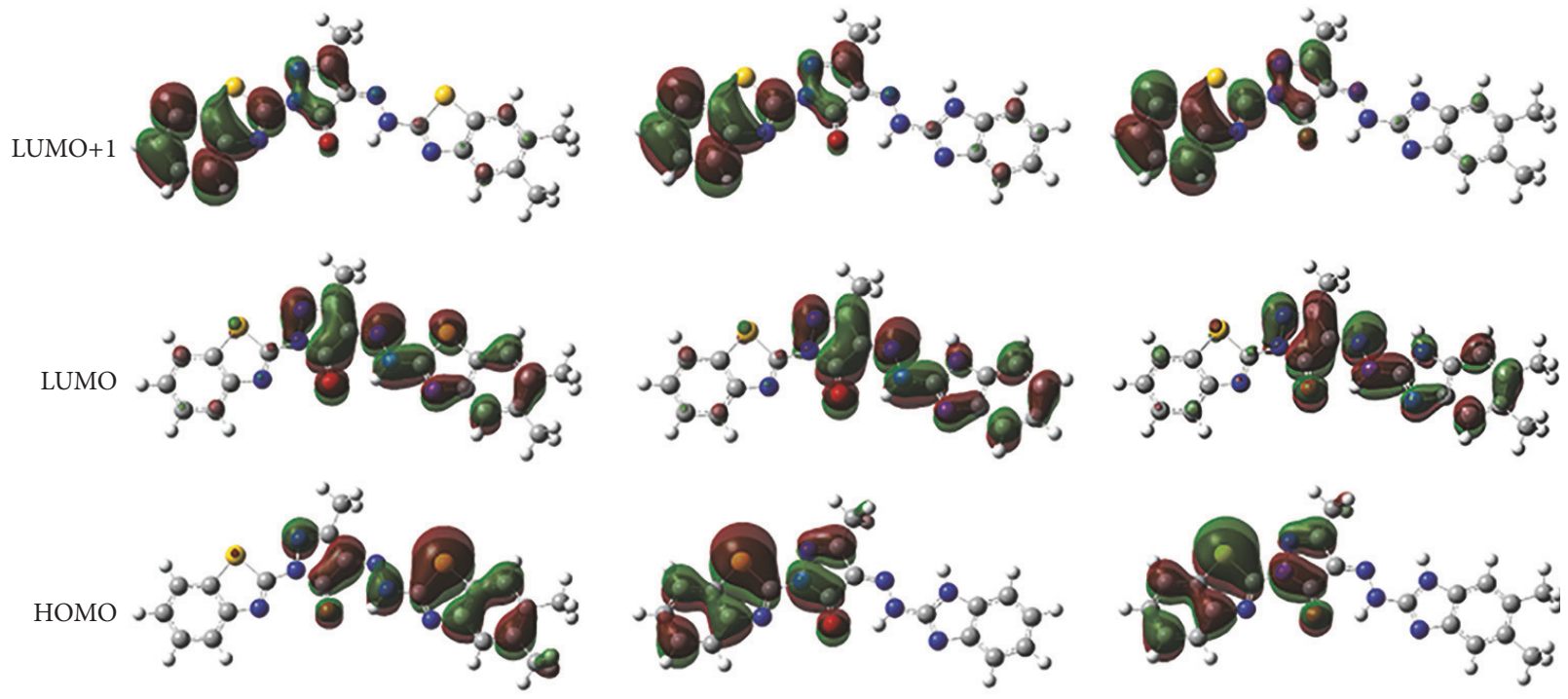

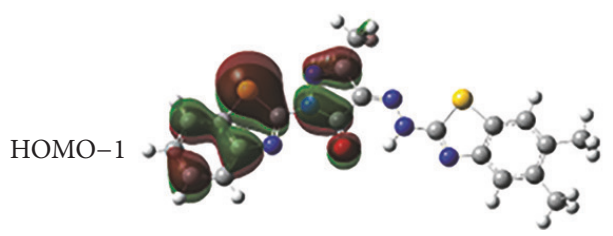

$3 d$

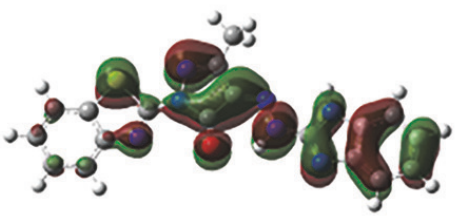

$3 e$

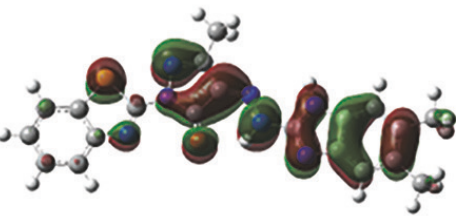

$3 f$

FIgURE 7: The frontier molecular orbitals of the dyes 3a-3f.

are mainly localized on pyrazole and benzothiazolyl diazo moiety. The main peaks in UV-Vis spectra are attributed to the HOMO-LUMO electronic transitions. As seen from Table 8 , the increase in the wavelength values is in agreement with bathochromic shifts and $\Delta E$ decreasing. The electron densities in the HOMOs of the dyes $3 \mathrm{e}$ and $3 \mathrm{f}$ are mainly localized on pyrazole and benzothiazole moiety while electron densities in their LUMOs are localized on pyrazole and benzimidazolyl diazo moiety.

\section{Conclusions}

A series of azo dyes based on benzothiazolyl pyrazole and simultaneously benzothiazolyl and benzimidazolyl diazo 
TABLE 8: HOMO and LUMO energies (eV), energy gaps $(\Delta E)$, and $\lambda_{\max }$ values $(\mathrm{nm})$ of azo dyes $3 \mathrm{a}-3 \mathrm{f}$ calculated in chloroform.

\begin{tabular}{lcccc}
\hline Dye & $\lambda_{\max (\text { calc.) }}{ }^{\mathrm{a}}$ & $E_{\text {LUMO }}$ & $E_{\text {HOMO }}$ & ${E g}_{\text {(calc) }}$ \\
\hline 3a & $433(0.9087)$ & -3.26 & -6.35 & 3.08 \\
3b & $439(0.9685)$ & -3.33 & -6.37 & 3.04 \\
3c & $488(0.8218)$ & -3.17 & -6.02 & 2.85 \\
3d & $462(0.8391)$ & -3.21 & -6.22 & 3.01 \\
3e & $447(0.9126)$ & -3.18 & -6.22 & 3.04 \\
3f & $480(0.8510)$ & -3.13 & -5.99 & 2.87 \\
\hline
\end{tabular}

${ }^{\mathrm{a}}$ Oscillator strength values are given in parentheses.

moieties were synthesized and characterized by elemental analyses, FT-IR, ${ }^{1} \mathrm{H}$ NMR spectra, and DFT calculations. Absorption spectra of the dyes were reported both experimentally and theoretically by TD-DFT calculations. The absorption maxima of the hetarylazopyrazolone dyes bearing benzothiazolyl diazo moiety showed bathochromic shifts because these dyes give easily acidic protons to the solvent like DMF and DMSO. The maximum absorption values obtained with TD-DFT/B3LYP method using nonequilibrium procedure are in a good agreement with the experimental results.

\section{Conflicts of Interest}

The authors declare that there are no conflicts of interest regarding the publication of this paper.

\section{Acknowledgments}

This work has been supported by the Gazi University Research Fund through Grant no. 05/2002-08.

\section{References}

[1] H. Zollinger, Color Chemistry: Synthesis, Properties and Applications of Organic Dyes and Pigments, Wiley VCH, 3rd edition, 2003.

[2] J. Koh, H. Kim, J. Lee, and M. Eom, "Dyeing and fastness properties of phthalimide-based alkali-clearable azo disperse dyes on poly(ethylene terephthalate)," Coloration Technology, vol. 125, no. 6, pp. 322-327, 2009.

[3] G. Hussain, M. Ather, M. U. A. Khan et al., "Synthesis and characterization of chromium (III), iron (II), copper (II) complexes of 4-amino-1-(p-sulphophenyl)-3-methyl-5-pyrazolone based acid dyes and their applications on leather," Dyes and Pigments, vol. 130, pp. 90-98, 2016.

[4] X. Tong and Y. Zhao, "Multiple photochemical processes in liquid crystalline azo dye-doped liquid crystals," Chemistry of Materials, vol. 21, no. 17, pp. 4047-4054, 2009.

[5] A. V. Uklein, E. V. Ouskova, and V. Y. Gayvoronsky, "Nonlinear optical response of the nematic liquid crystal doped with polymer-azo-dye complex under picosecond laser pulses excitation," Functional Materials, vol. 22, no. 1, pp. 20-26, 2015.

[6] S. B. Novir and S. M. Hashemianzadeh, "Density functional theory study of new azo dyes with different $\pi$-spacers for dyesensitized solar cells," Spectrochimica Acta Part A: Molecular and Biomolecular Spectroscopy, vol. 143, pp. 20-34, 2015.
[7] R. V. Solomon, R. Jagadeesan, S. A. Vedha, and P. Venuvanalingam, "A DFT/TDDFT modelling of bithiophene azo chromophores for optoelectronic applications," Dyes and Pigments, vol. 100, no. 1, pp. 261-268, 2014.

[8] M. Matsuoka, Infrared Absorbing Dyes, Plenum Press, New York, NY, USA, 1990.

[9] S. Erişkin, N. Şener, S. Yavuz, and I. Şener, "Synthesis, characterization, and biological activities of 4-imino-3-arylazo- $4 \mathrm{H}$ pyrimido[2,1-b][1,3]benzothiazole-2-oles," Medicinal Chemistry Research, vol. 23, no. 8, pp. 3733-3743, 2014.

[10] B. Minisini, G. Messager, I. Piyanzina, N. Delorme, and J.-F. Bardeau, "Vibrational analysis of [4-[(E)-phenylazo] phenyl] ethanol based on the comparison between the experimental and DFT calculated raman spectra," Journal of Structural Chemistry, vol. 55, no. 5, pp. 843-851, 2014.

[11] M. S. Deshmukh and N. Sekar, "A combined experimental and TD-DFT investigation of three disperse azo dyes having the nitroterephthalate skeleton," Dyes and Pigments, vol. 103, pp. 25-33, 2014.

[12] S. Harisha, J. Keshavayya, B. E. K. Swamy, and C. C. Viswanath, "Dyes and pigments synthesis, characterization and electrochemical studies of azo dyes derived from barbituric acid," Dyes and Pigments, vol. 136, pp. 742-753, 2017.

[13] S. A. Basaif, M. A. Hassan, and A. A. Gobouri, " $\mathrm{AlCl}_{3}$-Catalyzed diazocoupling of 1-(aryl/hetaryl)-3-phenyl-1H-pyrazol-2-in-5ones in aqueous medium. Synthesis of hetaryl-azopyrazolones and their application as disperse dyes," Dyes and Pigments, vol. 72, no. 3, pp. 387-391, 2007.

[14] B. Babür, N. Seferoğlu, E. Aktan, T. Hökelek, E. Şahin, and Z. Seferoğlu, "Phenylazoindole dyes 3: determination of azohydrazone tautomers of new phenylazoindole dyes in solution and solid state," Journal of Molecular Structure, vol. 1081, pp. 175181, 2015.

[15] T. Aksungur, Ö. Arslan, N. Seferolu, and Z. Seferolu, "Photophysical and theoretical studies on newly synthesized N,Ndiphenylamine based azo dye," Journal of Molecular Structure, vol. 1099, pp. 543-550, 2015.

[16] Y. Li, B. O. Patrick, and D. Dolphin, "Near-infrared absorbing azo dyes: synthesis and X-ray crystallographic and spectral characterization of monoazopyrroles, bisazopyrroles, and a boron-azopyrrole complex," The Journal of Organic Chemistry, vol. 74, no. 15, pp. 5237-5243, 2009.

[17] B. Babür, N. Seferoğlu, E. Aktan, T. Hökelek, E. Şahin, and Z. Seferoğlu, "Phenylazoindole dyes 2: the molecular structure characterizations of new phenylazo indoles derived from 1,2dimethylindole," Dyes and Pigments, vol. 103, pp. 62-70, 2014.

[18] S. Kinali, S. Demirci, Z. Çalişir, M. Kurt, and A. Ataç, "DFT, FTIR, FT-Raman and NMR studies of 4-(substituted phenylazo)3,5- diacetamido-1H-pyrazoles," Journal of Molecular Structure, vol. 993, no. 1-3, pp. 254-258, 2011.

[19] B. Minisini, G. Messager, I. Piyanzina, N. Delorme, and J.-F. Bardeau, "Vibrational analysis of [4-[(E)-phenylazo] phenyl] ethanol based on the comparison between the experimental and DFT calculated raman spectra," Journal of Structural Chemistry, vol. 55, no. 5, pp. 843-851, 2014.

[20] A. Pramanik and G. Das, "Molecular to supramolecular structure: influence of coordination environment in azo-dye complexes," Crystal Growth and Design, vol. 8, no. 8, pp. 3107-3113, 2008.

[21] K. J. Al-Adilee, A. K. Abass, and A. M. Taher, "Synthesis of some transition metal complexes with new heterocyclic thiazolyl azo 
dye and their uses as sensitizers in photo reactions," Journal of Molecular Structure, vol. 1108, pp. 378-397, 2016.

[22] N. Turan, R. Adigüzel, K. Buldurun, and E. Bursal, "Spectroscopic, thermal and antioxidant properties of novel mixed ligand-metal complexes obtained from saccharinate complexes and azo dye ligand (Mnppa)," International Journal of Pharmacology, vol. 12, no. 2, pp. 92-100, 2016.

[23] Ç. K. Atay, Y. Kara, M. Gökalp, I. Kara, T. Tilki, and F. Karci, "Disazo dyes containing pyrazole and indole moieties: Synthesis, characterization, absorption characteristics, theoretical calculations, structural and electronic properties," Journal of Molecular Liquids, vol. 215, pp. 647-655, 2016.

[24] F. Karci and F. Karci, "Synthesis of some novel pyrazolo[5,1c] $[1,2,4]$ triazine derivatives and investigation of their absorption spectra," Dyes and Pigments, vol. 76, no. 1, pp. 97-103, 2008.

[25] Ç. Karabacak and O. Dilek, "Synthesis, solvatochromic properties and theoretical calculation of some novel disazo indole dyes," Journal of Molecular Liquids, vol. 199, pp. 227-236, 2014.

[26] F. Karci and E. Bakan, "New disazo pyrazole disperse dyes: synthesis, spectroscopic studies and tautomeric structures," Journal of Molecular Liquids, vol. 206, pp. 309-315, 2015.

[27] N. Sener, I. Sener, S. Yavuz, and F. Karci, "Synthesis, absorption properties and biological evaluation of some novel disazo dyes derived from pyrazole derivatives," Asian Journal of Chemistry, vol. 27, no. 8, pp. 3003-3012, 2015.

[28] F. Karci, N. Şener, M. Yamaç, I. Şener, and A. Demirçali, “The synthesis, antimicrobial activity and absorption characteristics of some novel heterocyclic disazo dyes," Dyes and Pigments, vol. 80, no. 1, pp. 47-52, 2009.

[29] A. Emandi, I. Serban, and R. Bandula, "Synthesis of some new solvatochromic 1(4)-substituted Pyrazol-5-one Azo derivatives," Dyes and Pigments, vol. 41, no. 1-2, pp. 63-77, 1999.

[30] B. Babür, N. Seferoğlu, and Z. Seferoğlu, "A ratiometric fluorescence chemosensor based on a coumarin-pyrazolone hybrid: the synthesis and an investigation of the photophysical, tautomeric and anion binding properties by spectroscopic techniques and DFT calculations," Tetrahedron Letters, vol. 56, no. 17, pp. 2149-2154, 2015.

[31] B. Çatikkaş, E. Aktan, and E. Yalçin, "Vibrational and electronic investigations, NLO, FMO analysis on a hetarylazoindole disperse dye by density functional theory," Journal of Molecular Structure, vol. 1117, pp. 218-226, 2016.

[32] J. Jayabharathi, V. Thanikachalam, M. Venkatesh Perumal, and N. Srinivasan, "A physiochemical study of azo dyes: DFT based ESIPT process," Spectrochimica Acta-Part A: Molecular and Biomolecular Spectroscopy, vol. 83, no. 1, pp. 200-206, 2011.

[33] Ü. Ö. Özdemir, E. Aktan, F. Ilbiz et al., "Characterization, antibacterial, anticarbonic anhydrase II isoenzyme, anticancer, electrochemical and computational studies of sulfonic acid hydrazide derivative and its $\mathrm{Cu}(\mathrm{II})$ complex," Inorganica Chimica Acta, vol. 423, pp. 194-203, 2014.

[34] E. Yalçin, S. Achelle, Y. Bayrak, N. Seferolu, A. Barsella, and Z. Seferolu, "Styryl-based NLO chromophores: synthesis, spectroscopic properties, and theoretical calculations," Tetrahedron Letters, vol. 56, no. 20, pp. 2586-2589, 2015.

[35] G. Elmaci, E. Aktan, N. Seferoğlu, T. Hökelek, and Z. Seferoğlu, "Synthesis, molecular structure and computational study of (Z)-2-((E)-4-nitrobenzylidene)hydrazone)-1,2-diphenylethan1-one," Journal of Molecular Structure, vol. 1099, pp. 83-91, 2015.

[36] S. Alyar, H. Alyar, U. O. Ozdemir et al., "Synthesis, characterization, antibacterial activity and quantum chemical studies of
$\mathrm{N}^{\prime}$-acetyl propane sulfonic acid hydrazide," Journal of Molecular Structure, vol. 1094, pp. 237-245, 2015.

[37] Ü. Özmen Özdemir, A. Altuntaş, A. B. Gündüzalp, F. Arslan, and F. Hamurcu, "New aromatic/heteroaromatic propanesulfonylhydrazone compounds: synthesis, physical properties and inhibition studies against carbonic anhydrase II (CAII) enzyme," Spectrochimica Acta. Part A: Molecular and Biomolecular Spectroscopy, vol. 128, pp. 452-460, 2014.

[38] E. Aktan, N. Ertan, and T. Uyar, "Synthesis, characterization and theoretical study of new hetarylazopyrazolone dyes and investigation of their absorption spectra," Journal of Molecular Structure, vol. 1060, pp. 215-222, 2014.

[39] M. J. Frisch, G. W. Trucks, H. B. Schlegel et al., Gaussian 09, Revision A.02, Gaussian Inc, Wallingford, Conn, USA, 2009.

[40] J. Tomasi, B. Mennucci, and E. Cancès, "The IEF version of the PCM solvation method: an overview of a new method addressed to study molecular solutes at the QM ab initio level," Journal of Molecular Structure: THEOCHEM, vol. 464, no. 1-3, pp. 211-226, 1999.

[41] M. Cossi and V. Barone, "Time-dependent density functional theory for molecules in liquid solutions," Journal of Chemical Physics, vol. 115, no. 10, pp. 4708-4717, 2001. 

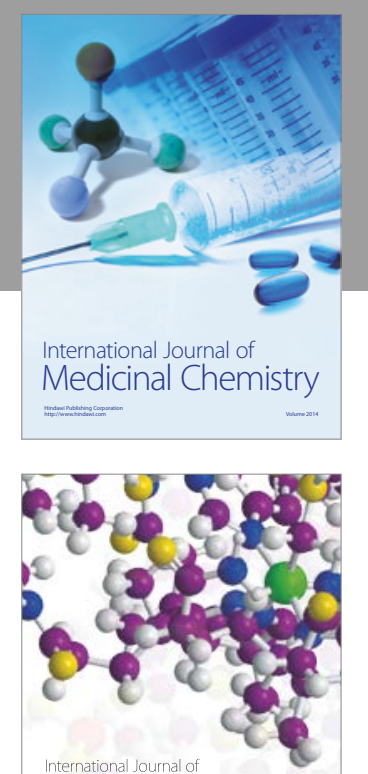

Carbohydrate Chemistry

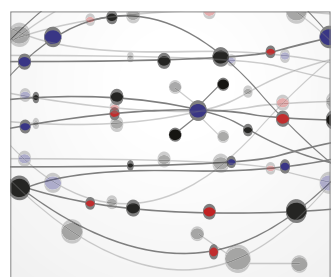

The Scientific World Journal
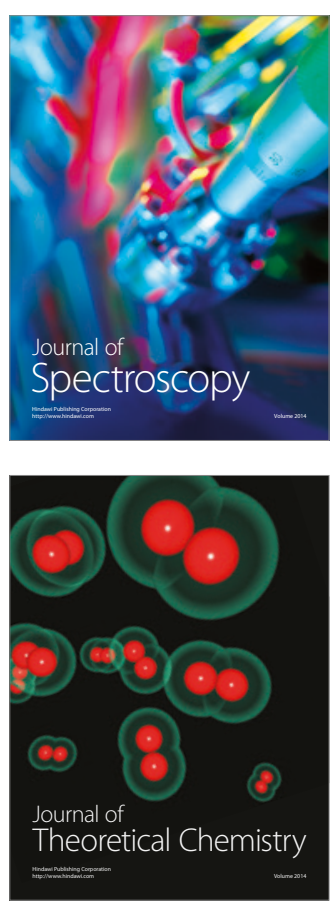
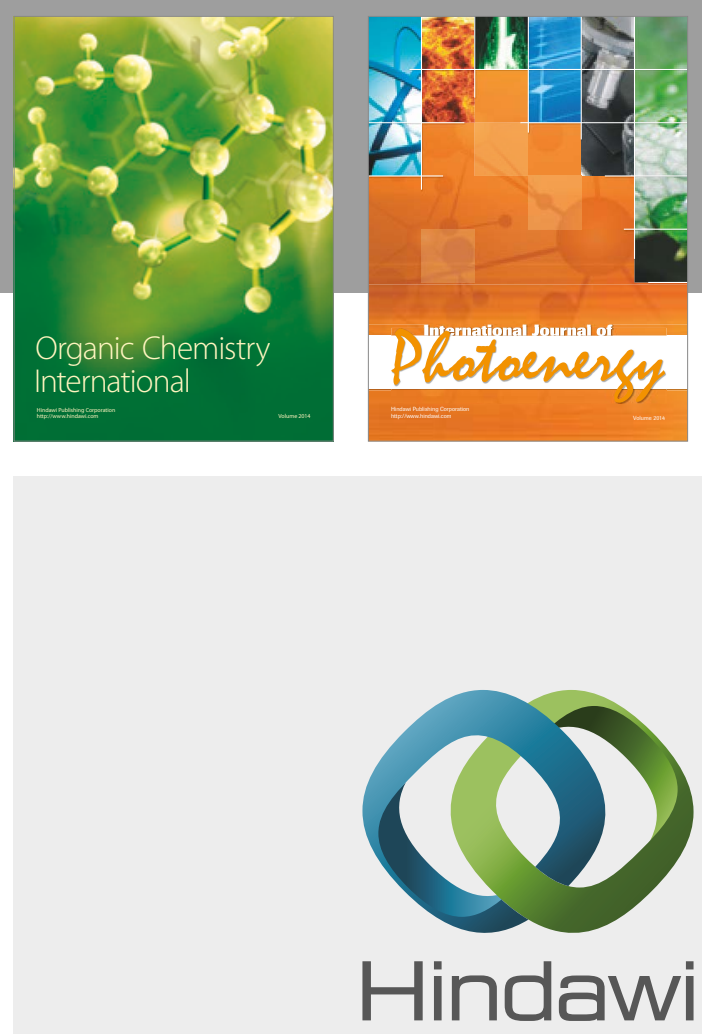

Submit your manuscripts at

https://www.hindawi.com

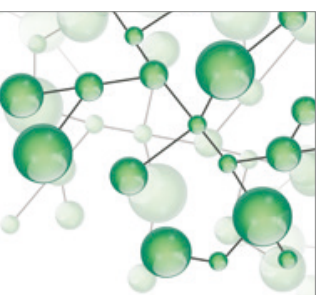

International Journal of

Inorganic Chemistry

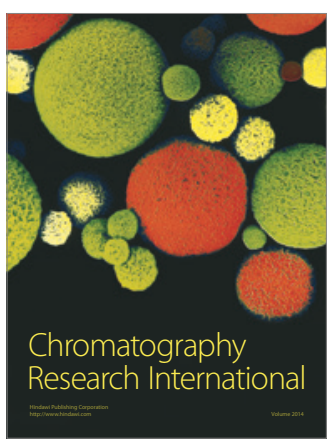

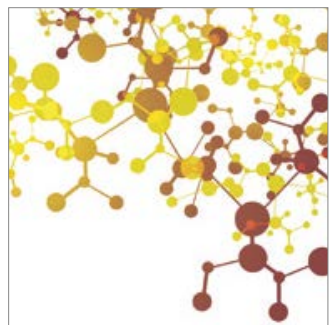

Applied Chemistry
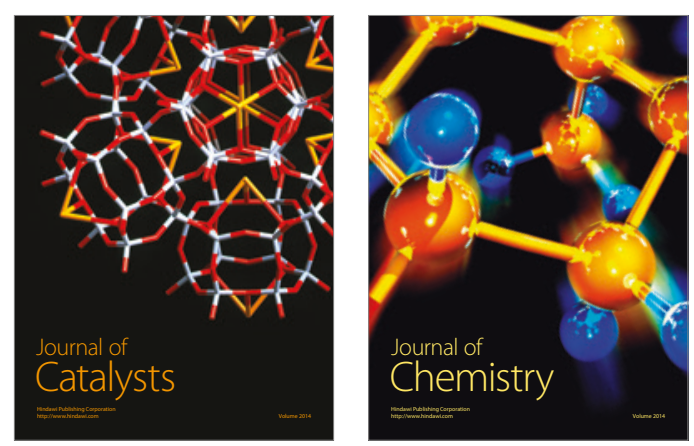
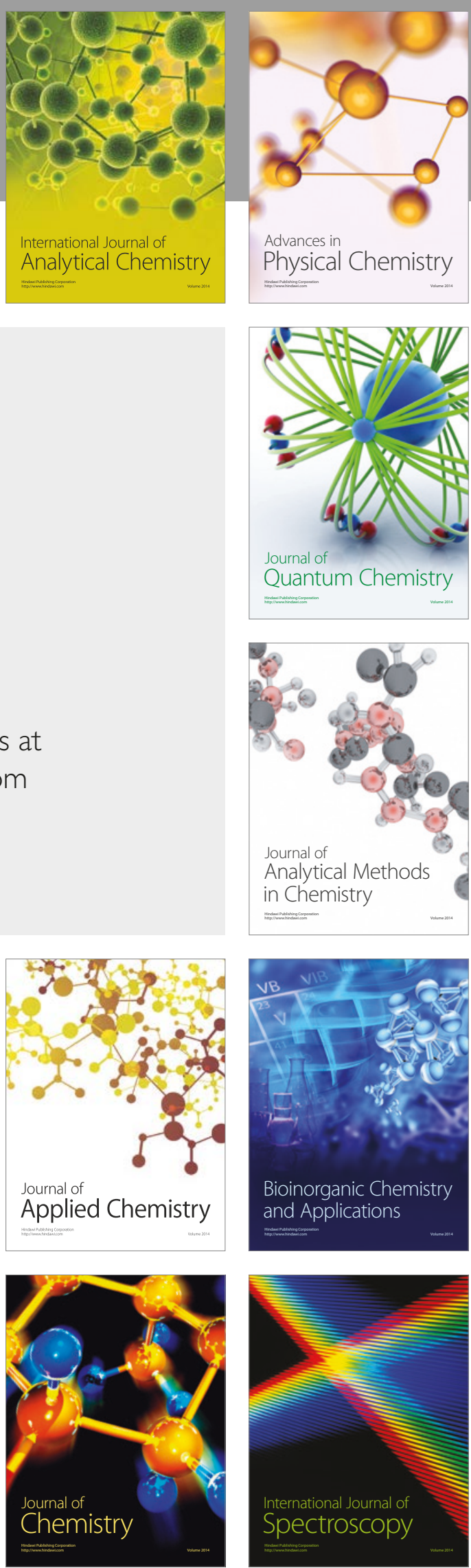